Dzieje Najnowsze, Rocznik LIII - 2021, 2

PL ISSN 0419-8824

\title{
Stanisław Sierpowski
}

https://orcid.org/0000-0001-8458-8486

Profesor senior Uniwersytetu im. Adama Mickiewicza w Poznaniu

\section{Sąd nad Manfredim Graviną, Wysokim Komisarzem Ligi Narodów w Wolnym Mieście Gdańsku w latach 1929-1932}

\begin{abstract}
Abstrakt: Autor artykułu podejmuje próbę racjonalizacji funkcjonowania wysokich komisarzy Ligi Narodów w Wolnym Mieście Gdańsku. Koncentruje się na osobie włoskiego Wysokiego Komisarza Manfrediego Graviny, działającego na terenie Wolnego Miasta w latach 1929-1932. Stara się zdjąć z niego etykietę polityka antypolskiego.
\end{abstract}

Słowa klucz ow e: Manfredi Gravina, Liga Narodów, Wolne Miasto Gdańsk.

Abstract: The article attempts to rationalise the functioning of the League of Nations High Commissioners in the Free City of Danzig (Gdansk). It focuses on the person of High Commissioner Manfredi Gravina of Italian nationality, active in the Free City in 1929-1932, trying to remove from him the label of an anti-Polish politician.

Key w or d s: Manfredi Gravina, League of Nations, Free City of Danzig (Gdansk).

Nie stanowi nadmiernego ryzyka stawianie tezy, że gdańska polityka Ligi Narodów (LN) była funkcją miejsca i roli w stosunkach europejskich Niemiec oraz ewolucji stosunków polsko-niemieckich. Cezura roku 1934 jest dla wielu autorów powszechnie przyjmowana ${ }^{1}$. Z punktu widzenia LN, dominującego

${ }^{1}$ Cezurę roku 1934 wyeksponowali Wolfgang Ramonat, autor obszernej i dobrze udokumentowanej książki Der Völkerbund und die Freie Stadt Danzig 1920-1934, Osnabrück 1979 (t. XVIII serii „Studien zur Militärgeschichte, Militärwissenschaft und Konfliktforschung”), 
w tym tekście, polsko-niemiecka deklaracja o niestosowaniu przemocy oznaczała nasilenie procesu dystansowania się Genewy od spraw Wolnego Miasta. Najbardziej skonfliktowanym na tym tle państwom organy LN - jako instytucji sprawujacej opiekę nad Gdańskiem - regularnie zalecały prowadzenie dwustronnych negocjacji. Stało się to konieczne, gdy jesienią $1933 \mathrm{r}$. Niemcy wystąpiły z Ligi, utrzymując jednak wybitne zainteresowanie sytuacją w Gdańsku.

Wolne Miasto Gdańsk wedle zamysłu jego twórców miało - zachowując administracyjną odrębność - służyć gospodarce Polski. Założenie zgodnej, opartej na przepisach prawa współpracy okazało się iluzoryczne. Minister Józef Beck zdając sam sobie (aczkolwiek z myśla o potomnych) „ostatni raport”, uznał, że statut Wolnego Miasta był chyba „najdziwaczniejszym i najbardziej skomplikowanym tworem traktatu wersalskiego [...] ujęto go tak, ażeby zachować teren sporów polsko-niemieckich lub co najmniej materiał do handlu interesami polskimi na korzyść Niemiec"2.

LN, a de facto jej Rada opiekę nad Wolnym Miastem sprawowała za pośrednictwem wysokich komisarzy rezydujących w Gdańsku. Desygnowanie na to stanowisko wymagało akceptacji Senatu Wolnego Miasta, rządu polskiego oraz jednomyślnej decyzji Rady. Od uzyskania przez Niemcy stałego miejsca w Radzie w 1926 r. do znalezienia konsensusu koniecznych było wiele zakulisowych narad i pertraktacji. Nieustępliwa postawa następców Gustava Stresemanna uniemożliwiła przedłużenie kadencji Joosta van Hamela, dyplomaty holenderskiego, wysokiego komisarza w latach 1926-1929 ${ }^{3}$.

Jego następcą został Manfredi Gravina, którego wyłoniono bez większych komplikacji. Rzecznikiem jego powołania był zaprzyjaźniony z nim baron Ernst von Weizsäcker - członek biura LN Auswärtiges Amt. Jako częsty członek delegacji niemieckiej na sesje Zgromadzeń lub Rady spotykał się z Gravina, który od 1924 r. także uczestniczył w pracach genewskich jako członek delegacji włoskiej. Do kandydatury Graviny od samego początku życzliwie odnosił się także minister August Zaleski.

Baron Manfredi Gravina ukończył Akademię Morską w Livorno. Podczas wojny był szefem gabinetu adm. Thaona di Revela. Rzemiosło dyplomatyczne poznawał jako kapitan marynarki włoskiej, z której ramienia uczestniczył w kilku komisjach międzynarodowych, m.in. w sprawie Westerplatte

oraz Ch.M. Kimmich, The Free City Danzig and German Foreign Policy 1919-1934, New Haven-London 1968. Literatura do tematu gdańskiego jest ogromna. Po polsku problem ten całościowo ują Stanisław Mikos w pożytecznej monografii Wolne Miasto Gdańsk a Liga Narodów 1920-1939, Gdańsk 1979. Jedyny monograficzny artykuł o Manfredim Gravinie ogłosił po włosku i po polsku Ettore Deodato (tekst dostępny w Wielkopolskiej Bibliotece Cyfrowej). E. Deodato, Manfredi Gravina - Wysoki Komisarz Ligi Narodów w Gdańsku (czerwiec 1929 - wrzesień 1932), „Studia Historica Slavo-Germanica” 1989, t. XV, s. 124-152.

2 J. Beck, Ostatni raport, Warszawa 1987, s. 34.

${ }^{3}$ S. Mikos, op. cit., s. 151 i n.; S. Sierpowski, Liga Narodów w najlepszym czasie 1926-1929, Poznań 2018, s. 349 i n. 
w październiku 1925 r. W latach 1919-1922 w Sztokholmie i Kopenhadze piastował stanowisko attaché morskiego przy państwach skandynawskich. Był aktywistą ruchu nacjonalistycznego, z którym przyłączył się do Narodowej Partii Faszystowskiej; został jej członkiem w 1923 r. ${ }^{4}$

Gravina przybył do Gdańska 24 VI 1929 r., rozpoczynając trzyletnia kadencję jako przedstawiciel LN. Jego pierwszym i głównym zadaniem było rozstrzyganie na miejscu sporów i konfliktów, związanych z funkcjonowaniem Wolnego Miasta, zgodnie z konstytucja oraz umowami zawartymi z Polska. Wypełnienie tej misji przez Gravinę stało się trudne z powodu wzrostu tendencji nacjonalistycznych, a nawet szowinistycznych, współkształtowanych przez hitlerowskich emisariuszy z Rzeszy. Nasilały się agresywne wystapienia przeciwko mniejszości polskiej oraz żydowskiej.

Konflikty, niemożliwe do rozwiązania przez wysokiego komisarza, były w formie skarg - jednej lub obu stron - przekazywane do Rady LN. Wszczęta tam procedura czyniła z danego konfliktu problem międzynarodowy, w którym uczestniczyły $-\mathrm{z}$ reguły niezbyt chętnie - wszystkie państwa reprezentowane w Radzie. Referentem spraw gdańskich w Radzie został przedstawiciel Wielkiej Brytanii. Jego rola była ważna również przez to, że często w imieniu Rady prowadził wstępne rozmowy mające na celu znalezienie kompromisu ${ }^{5}$. W pewnym sensie kontynuował misję, której nie zdołał pozytywnie zakończyć wysoki komisarz na miejscu.

Ustrój Wolnego Miasta był tak ułożony, że jego funkcjonowanie zależało przede wszystkim od dobrej woli Senatu gdańskiego. Ani LN, ani rząd polski nie posiadały na terenie Gdańska żadnej realnej egzekutywy. Tworząc Wolne Miasto, zakładano, że autorytet wysokiego komisarza, plenipotenta LN, będzie miał rozstrzygajace znaczenie, od początku redukowane do moralnego nacisku. Jego założona bezstronność w ocenie sytuacji, obserwowanej na miejscu i bez uprzedzeń, stanowiła główne źródło pretensji wszystkich zainteresowanych stron, że ich punkt widzenia i oczekiwania nie zostały w sposób należyty uwzględnione. $\mathrm{Z}$ wielkim trudem radzi sobie $\mathrm{z}$ tym także historiografia...

Subiektywizm w ocenie każdej inicjatywy lub decyzji wysokiego komisarza wpisywał się w jego kontrowersyjnie oceniana działalność. Oceny te były bardziej wyraziste, jeśli towarzyszyła im niechęć do instytucji, która reprezentował. W tym wypadku państwo i społeczeństwo niemieckie wyjątkowo skonsolidowało się. Genewa była synonimem zła i kozłem ofiarnym jednocześnie. LN, z cała swoją pacyfistyczna frazeologia, w tych państwach i społeczeństwach traktowano z równą niechęcią i nienawiścią jak i traktaty

\footnotetext{
${ }^{4}$ E. Tollardo, Fascist Italy and the League of Nations, 1922-1935, London 2016, s. 163. Wiele szczegółów podaje S. Mikos, op. cit., s. 223 i n.

${ }^{5}$ Anique H.M. van Ginneken (Historical Dictionary of the League of Nations, Oxford 2006, s. 72) napisała, że Arthur Henderson, występujący w roli sprawozdawcy, potrafił na „pewien czas uspokoić obie strony".
} 
pokojowe. Dążenie do ich zmian było przemożne i narastało. Oferowane przez Ligę możliwości zmian, choćby uwidocznione w art. 19 paktu, okazały się iluzoryczne. W tej sprawie pat był kompletny.

Informacje dotyczące sytuacji wewnętrznej Wolnego Miasta wywoływały z reguły pretensje i oskarżenia, formułowane przez obie strony. Gabriele C. Bordonaro, konsul włoski w Gdańsku, informując Palazzo Chigi o trudnej sytuacji Graviny na marginesie sporów wywołanych jego raportem z września 1931 r., pisał, że ataki kierowane przeciwko wysokiemu komisarzowi sa zupełnie nieuzasadnione, ponieważ dla bezstronnego czytelnika jego raport stanowi tylko wierne zwierciadło sytuacji. Problem w tym, „że tutaj wytworzyła się mentalność, według której wszystko jest ograniczone do warunków miejscowych. I w ten sposób bezrobocie, zastój w gospodarce nie sa dla Gdańszczan odbiciem światowego kryzysu, ale konsekwencja umyślnego szkodzenia ze strony Polski. A z drugiej strony zamiast starać się osiagnąć porozumienie z Polakami, okazuje się im największą pogardę i nie pomija się żadnej okazji, aby zamanifestować swoje przywiazanie do Niemiec, wsparte życzeniem połączenia z Rzesza. [...] publiczne ujawnienie takiej prawdy nie może być przyjemne dla tych, którzy są odpowiedzialni za sytuację istniejąca w Gdańsku"6.

Wysokich komisarzy, aczkolwiek pośrednio, predestynowano do poszukiwania rozwiązań, które mogłyby umniejszyć lub nawet wyeliminować stałe napięcie i wzajemną chęć odwetu. Byli wystawieni na krytykę nie tylko, kiedy podejmowali decyzję, ale także gdy pisali raporty do Sekretariatu LN, przekazując konkretne informacje, rzadziej własne wrażenia i obserwacje. To one najczęściej były stronniczo i wybiórczo odczytywane, nie tylko w Gdańsku, ale również w Berlinie czy Warszawie. Należy zauważyć, że wysocy komisarze nie do końca byli autorami raportów. Ustaliła się praktyka, że pierwotny tekst raportu rocznego przekazywali do wiadomości Sekretariatu LN i dopiero po takiej konsultacji wysyłano tekst sekretarzowi generalnemu z prośbą o rozesłanie do członków Rady $\mathrm{LN}^{7}$.

W przekazywanych do Genewy raportach wysocy komisarze skrupulatnie odnotowywali każdy przejaw świadczący o poprawie stosunków między władzami Senatu a polskim Komisariatem Generalnym. W podtekście traktowali to jako efekt własnej koncyliacyjnej działalności. Za bardzo szkodliwe dla rozwoju relacji wewnętrznych dość zgodnie i przez cały czas uważali wszelkie manifestacje, zarówno gdańskie, jak i ogólnoniemieckie, wynoszące na pierwsze miejsce powrót Gdańska do Rzeszy.

${ }^{6}$ Cyt. za: E. Deodato, op. cit., s. 142-143.

${ }^{7}$ Liczne ślady tej praktyki występują w digitalizowanym obecnie Archiwum Ligi Narodów. Zob. LONTAD, Recherche Entreprise, biblio-archive.unog.ch. Sa to materiały zwykle dwujęzyczne. Strasburger i Ernst Ziehm korespondowali w swoich językach, a pracownicy Wysokiego Komisariatu za czasów Graviny tłumaczyli na francuski; w Sekretariacie dodatkowo na angielski. Były publikowane w „Journal Officiel”. 
Raporty i informacje przekazywane przez Gravinę do Genewy ograniczały się w zasadzie do referowania sprzecznych deklaracji i oświadczeń polskich i gdańskich. Świadom był jednak powagi sytuacji, gdy wiosną 1931 r. przytaczał słowa Komisarza Generalnego RP, że wyczerpał on będace w jego dyspozycji środki mające nakłonić Senat gdański to zagwarantowania skutecznej ochrony obywateli polskich i ich majątku. Henryk Strasburger skarżył się, że nie otrzymuje zadowalających odpowiedzi od Senatu w powyższej kwestii. Wobec tego $\mathrm{w}$ imieniu rządu polskiego zadał pytanie wysokiemu komisarzowi, w jakim zakresie LN mogłaby zapewnić Polakom ochronę, której obecnie w Gdańsku brakuje. Wysoki komisarz - pisał w raporcie Gravina - jedynie stwierdził, że ta kwestia nie należy do obowiązków ani kompetencji Ligi, ale władz gdańskich8 ${ }^{8}$

Ogólny kontekst słów Strasburgera można sprowadzić do tego, że starał się zachęcić, może nawet nakłonić, aby zaprosić rząd polski do udzielenia wysokiemu komisarzowi pomocy w celu utrzymania porządku i zagwarantowania bezpieczeństwa w Wolnym Mieście. Gravina jednak nie podzielał tak skrajnej oceny sytuacji wewnętrznej Wolnego Miasta. Jego stanowisko znalazło zrozumienie sekretarza generalnego Erica Drummonda, który zalecał wysokim komisarzom unikanie ingerencji w wewnętrzne sprawy Gdańska. Ta ukształtowana przez Sekretariat doktryna była częścia składową aktywności kolejnego sekretarza generalnego, Josepha Avenola. W rozmowie z Edwardem Raczyńskim 9 XI 1933 r. w sposób wyraźny ograniczał on rolę wysokiego komisarza do informowania Rady o przestrzeganiu konstytucji gdańskiej, dbania o należyte wykonanie jej klauzul „mających zastosowanie przede wszystkim do ochrony istnienia i samodzielnego funkcjonowania Wolnego Miasta, jako instytucji”. Ingerowanie przez wysokiego komisarza w sprawy, które mogą mieć tylko incydentalny charakter, nie znajduje uzasadnienia, natomiast konieczne „sa starania o unikanie irytacji z powodu polemik, sugestii, zewnętrznych komentarzy, zmierzających do wyolbrzymienia odpowiedzialności Ligi"”.

Poruszenie wywołane przez inicjatywę Strasburgera stało się elementem rozwijanej z wielkim zapałem przez Niemców - tzw. wojny prewencyjnej, mającej się zacząć zajęciem Wolnego Miasta przez Polskę ${ }^{10}$.

W historiografii polskiej ukształtował się obraz negatywny lub co najmniej niechętny włoskiemu urzędnikowi Ligi w Gdańsku. Nie bez podstaw. Gravina wprawdzie zdecydowanie protestował przeciwko łączeniu jego nazwiska

\footnotetext{
8 „Journal Officiel de la Société des Nations” 1931, s. 1479 i n. Stare i nowe sprawy gdańskie były omawiane nawet podczas nadzwyczajnej sesji Rady w Paryżu 10 XII 1931 r., kiedy trudzono się nad znalezieniem rozwiązania po zajęciu przez Japonię chińskiej Mandżurii. Ibidem, s. $2245 \mathrm{n}$.

${ }^{9}$ Archives de la Société des Nations, Genewa (dalej: ASDN), Archives of Avenol, P. 34 (materiał nieuporządkowany).

${ }^{10}$ Przywiązanie polskiej publicystyki historycznej do tezy o wojnie prewencyjnej objęło także Teatr Telewizji TVP, gdzie wystawiono nagradzana sztukę poświęconą tej sprawie. Najbardziej mnie zaskoczyło nazwisko konsultanta prof. Jana Żaryna.
} 
z dążeniem do rewizji systemu wersalskiego, ale był przywiązany do słów swojego premiera, że traktaty nie są wieczne i podlegaja, jak wszystko na tym świecie, przemijaniu. Słowa te zreszta znalazły się $\mathrm{w}$ jednym $\mathrm{z}$ jego pierwszych przemówień, które wygłosił w lipcu 1929 r. w Gdańsku. Było ono podwójnie charakterystyczne, gdyż tekst został skonsultowany najpierw z przedstawicielami obu stron. Strasburger, który do pierwotnego tekstu wprowadził kilka drobnych poprawek, miał oświadczyć, że „dla każdej osoby pozbawionej uprzedzeń tekst był jasny i zgodny z moja misja" ${ }^{11}$.

Zarazem, zwłaszcza w pierwszych kilku miesiącach pobytu w Gdańsku, Gravina nie krył się specjalnie, także przed polskimi urzędnikami w Wolnym Mieście, że wierzy w zwycięstwo ruchu hitlerowskiego, który przeprowadzi w najszerszym zakresie program rewizjonistyczny: „na pierwszym miejscu w tym planie znajdować się będzie Gdańsk"12. W rozmowie z Komisarzem Generalnym RP w listopadzie 1931 r. stwierdził, że co „roku razem z żona widuje Hitlera (nie wiem gdzie? w Berlinie czy w Bayreuth?) i że Hitler robi na nim wrażenie człowieka bardzo mąrego. Gravina nazywa go małym Mussolinim...”13

$\mathrm{Z}$ tą wiedzą nieco mniej dziwią notatki Josepha Goebbelsa ze spotkania z Gravina 16 XI 1930 r. w Wolnym Mieście. „To jest nasz człowiek” - zanotował gość, zapewne mile połechtany słowami gospodarza: ,jeszcze tylko narodowi socjaliści sa prawdziwymi facetami w Niemczech". Goebbels miał pewność, że „położenie Gdańska jest rozpaczliwe. Wszystkie traktaty są korzystne dla Polski. Gravina robi co może, aby chronić nasze prawa"14.

Uwagi te w zasadzie mogłyby zamknać różne spojrzenia na pełnienie przez Gravinę funkcji wysokiego komisarza. Można pójść utartym już szlakiem, że Gravina nie czuł się w pierwszym rzędzie reprezentantem LN. Będąc Włochem, w dodatku jednym z szermierzy ruchu nacjonalistycznego, liczył się głównie z opinią Benita Mussoliniego i ówczesnych liderów państwa. Ci zaś już wówczas, co na arenie ligowej było widoczne, wybrali Niemcy, które za najważniejszy obiekt planów rewizyjnych obrali Polskę, w dodatku sojuszniczkę nielubianej Francji. Konieczność zmiany statusu Wolnego Miasta należała do kanonów i priorytetów wszelkich kombinacji mających usatysfakcjonować zjednoczone w swoim proteście społeczeństwo niemieckie. Gravina był przekonany, że złe rozwiązania, do których zaliczał także utworzenie Wolnego Miasta Gdańska, powinny być zmienione. Więcej nawet - dla normalnego, pokojowego funkcjonowania narodów są one konieczne.

Podobne przekonania zbliżały Gravinę do organizacji i sił politycznych głoszacych program rewizjonistyczny w stosunku do systemu wersalskiego. Nastawiały

${ }^{11}$ Cyt. za: E. Deodato, op. cit., s. 131, przypis 10.

12 Referat wygłoszony w zamkniętym gronie w MSZ w Warszawie w końcu 1938 r. S. Sierpowski, Źródła do historii powszechnej okresu międzywojennego, t. III, Poznań 1992, s. 274 (dostępne w WBC).

${ }_{13}$ Polskie Dokumenty Dyplomatyczne, 1931, red. M. Wołos, t. VIII, Warszawa 2008, s. 714.

14 J. Goebbels, Dzienniki, t. I: 1923-1939, Warszawa 2013, s. 154. 
do niego nieprzyjaźnie Komisarza Generalnego RP, który poza wszystkim nie odnajdywał w nim równorzędnego partnera. Strasburger raportując niekończące się kłótnie gdańsko-polskie, występował do pewnego stopnia w roli sędziego we własnej sprawie. Tymczasem chociaż Gravina nazywał go polskim nacjonalista, nie obciążał on specjalnie Strasburgera, starając się równo rozkładać winy i zasługi. Raporty publikowano. Każdy był analizowany przez wszystkie zainteresowane strony, wywołując polemiki, nawet żądania sprostowań.

Ogromnie pokomplikowane położenie Wolnego Miasta oraz jego relacje z Polską trzeba dodać do grupy tzw. czynników obiektywnych. Dla dbających o swoje interesy stron znalezienie modus vivendi w każdej sprawie było iście cierniową droga. Wielu $\mathrm{z}$ nich po prostu $-\mathrm{w}$ istniejacych warunkach geopolitycznych - nie dało się rozwiąać. Niemcy w aktywnym oczekiwaniu na powrót Gdańska do Rzeszy byli niemal jednomyślni; dla Polski takie rozwiązanie nie istniało. Oprócz tej centralnej sprawy niekończące się zadrażnienia występowały w stosunkach między Gdańskiem a Gdynią (bardzo dobrze prosperująca, a przy tym - co było ważne dla opinii zewnętrznej - położoną kilkanaście kilometrów od Gdańska) w związku z sytuacja mniejszości polskiej, w tym zwłaszcza katolickiej i żydowskiej, odprawami celnymi, walką z przemytem, niemiecką komunikacją z Prusami Wschodnimi, w ogóle powiązane z funkcjonowaniem kolei. Ponad tym wszystkim coraz większym brzemieniem była postępująca hitleryzacja codzienności gdańskiej. Gauleiterem w Gdańsku już w 1930 r. został Albert Forster. Miał 28 lat.

Europejska opinia publiczna dość zgodnie traktowała problem gdański jako jeden z najważniejszych zapalników nowej wojny. Dla pracy o charakterze dyplomatycznym był to teren bardzo trudny, dający nieliczne okazje do satysfakcji. W najbardziej znanej syntezie poświęconej LN, opracowanej przez Franka P. Waltersa, ówczesnego podsekretarza generalnego LN, napisano o Gravinie jako o cichym, rozsądnym wysokim komisarzu, który posiadając zaufanie obu stron, zapewnił miastu „rzadki stan spokoju”. To uznanie i zasługi były „na tyle istotne, że Rada zapytała go czy nie zechciałby służyć na druga trzyletnią kadencję"

W ligowej optyce, uwzględniającej punkt widzenia najważniejszych państw europejskich, była to propozycja wymowna. Zapowiedziane jego odejście zachęciło Radę do rozważenia na tajnym posiedzeniu brytyjskiej propozycji utrzymania go na tym stanowisku przez kolejne trzy lata. Gravina przychylił się do tego wniosku, zastrzegając jednocześnie prawo do rezygnacji z urzędu z przyczyn rodzinnych lub zdrowotnych, o czym jednak poinformuje Radę z półrocznym wyprzedzeniem. We wniosku brytyjskiego sprawozdawcy Rady ds. gdańskich wyrażono nadzieję, że Rada będzie „chciała skierować do hrabiego Graviny serdecznie podziękowania za życzliwość, z jaka był uprzejmy szybko zareagować na naszą prośbę, a jednocześnie wyrazić

${ }^{15}$ F.P. Walters, History of the League of Nations, t. I, Oxford 1952, s. 453-455. 
mu uznanie dla sposobu w jaki wypełniał swoje obowiązi”. Projekt uchwały zawierał formułę, że Rada mianuje Gravinę na Wysokiego Komisarza Ligi Narodów w Gdańsku na kolejne trzy lata, od 22 VI 1932 r., na tych samych warunkach, jakie zostały ustalone w rezolucji Rady z 21 IX $1928 \mathrm{r}^{16}$

W dotychczasowej praktyce relacji między Liga a Wolnym Miastem była to propozycja precedensowa, na którą musiały uprzednio wyrazić zgodę wszystkie zainteresowane strony. A te strony to jednomyślne stanowisko członków Rady LN (a więc i Niemiec, które od 1926 r. były stałym jej członkiem), Senat Wolnego Miasta oraz rząd polski. Nie pomniejszając głosu tego ostatniego w kontekście spraw gdańskich, trzeba zaznaczyć szczególną wagę opinii niemieckiej. Ich aktywny udział Niemiec w pracach genewskich niemal do końca 1933 r. bywał - raczej umiarkowanym, zawsze koniunkturalnym - hamulcem działań naruszających obowiązujące porozumienia, w tym zwłaszcza konstytucję gdańska, przez coraz głośniejszych zwolenników narodowego socjalizmu.

Zabiegi Graviny o spokój w Gdańsku znajdowały uznanie także w Warszawie, aczkolwiek per saldo dominuje w polskiej historiografii niechętna mu opinia. Do jej rozwoju rękę przyłożył minister Beck, który jednoznacznie stwierdził, że uprawiał on „politykę wyraźnie pro niemiecka” ${ }^{17}$. Problem w tym, że raczej wystawił sobie marną opinię jako jeden z najważniejszych realizatorów polityki zagranicznej Polski. Jeśli wybór Graviny na stanowisko wysokiego komisarza uznać za złe posunięcie ministra Zaleskiego w 1928 r., to decyzja o przedłużeniu jego kadencji, która zapadła w maju 1931 r., zapisuje się na konto Becka, który jako podsekretarz w Ministerstwie Spraw Zagranicznych miał na sprawy gdańskie specjalne baczenie. Polska wobec różnych propozycji dotyczących kandydatów na wysokiego komisarza już na etapie „przymiarek” eliminowała niewygodne lub niechciane osoby. Powtórzmy kolejny raz wysoki komisarz musiał mieć nie tylko jednomyślną rekomendację Rady LN, ale wcześniej uzyskać akceptację Senatu Wolnego Miasta i rządu polskiego. Dopiero wówczas nabierało mocy stanowisko Rady Ligi. Przedstawiciel Polski musiał głosować za drugą kadencją Graviny. Nawet jeśli by się wstrzymał, byłoby o tym głośno. Tymczasem wiemy, że August Zaleski na posiedzeniu Rady 20 maja „goraco” poparł wniosek sprawozdawcy ${ }^{18}$.

Henryk Stępniak piastowanie przez Gravinę stanowiska wysokiego komisarza uważa za niezbyt fortunne dla polskiego punktu widzenia i twierdzi, „że w literaturze utrzymuje się zgodny pogląd na temat antypolskiej postawy

${ }^{16}$ League of Nation Documents C.365.1931.I_FR. pdf,/Gravina/ Rapport du Représentant de la Grande-Bretagne; projekt rezolucji, uzgodniony w drodze wstępnych porozumień, brzmiał: „Rada mianuje hrabiego Gravinę na Wysokiego Komisarza Ligi Narodów w Gdańsku na nowy okres trzech lat, od 22 czerwca 1932 roku na takich samych warunkach jakie ustalono poprzednio”. Poza poparciem Zaleskiego innych głosów nie było; decyzja została przyjęta jednomyślnie 20 maja na posiedzeniu jawnym. Zob. „Journal Officiel” 1931, s. 1113.

17 J. Beck, op. cit., s. 35.

18 „Journal Officiel” 1931, s. 1113. 
większości wysokich komisarzy Ligi Narodów oraz pracowników sekretariatu Ligi [...] Manfredi Gravina, faszysta włoski, wysuną na jesieni 1931 roku propozycję rozszerzenia terytorium wolnego miasta przez włączenie do całego Pomorza polskiego (bez Pucka, Gdyni i Helu), tak aby Rzesza Niemiecka mogła komunikować się z Prusami wschodnimi przez terytorium gdańskie"19.

Swoistym streszczeniem tego nurtu w historiografii polskiej jest artykuł Marka Andrzejewskiego, jednego z najbardziej znanych historyków środowiska gdańskiego, który w 1981 r., podsumowując ówczesny dorobek historiografii dotyczącej relacji między LN i Wolnym Miastem, doszedł do wniosku, że wnuk Cosimy Wagner „należał do sympatyków hitleryzmu. Faworyzował on w sposób widoczny stronę gdańską i nie starał się zrozumieć polskiego punktu widzenia. Przez swój brak konsekwencji M. Gravina przyczynił się do osłabienia Ligi Narodów w Wolnym Mieście Gdańsku i nie był w stanie sprostać roli mediatora"20.

W syntezie dziejów powszechnych okresu międzywojennego uznałem wybór Graviny „za przejaw pewnej, chodź jeszcze niewielkiej zmiany” ${ }^{21}$. To bardzo duży skrót myślowy, powstały pod swoistym urokiem tezy, że dopiero zajęcie stanowiska reprezentowanego przez rząd polski byłoby satysfakcjonujacee. Twórcy Wolnego Miasta, co znajduje odbicie przede wszystkim w konstytucji gdańskiej, ale także w decyzjach podejmowanych zwłaszcza przez pierwszych wysokich komisarzy, mieli bardziej na uwadze interesy eksperymentalnie tworzonej enklawy terytorialnej, w której LN przypisano rolę protektora. W tej optyce ochrona i rozwój Wolnego Miasta stanowiły sprawę nadrzędna względem oczekiwań Polaków, powołujących się na pokojowy program Thomasa Woodrow Wilsona. Nie bez znaczenia było również to, że jego gwiazda w czasie kształtowania się zębów politycznych Wolnego Miasta przygasała, a po przegranej walce o reelekcję w $1921 \mathrm{r}$. zgasła.

Wysocy komisarze działali ze świadomościa tych realiów. Aktywność Graviny komplikowała niechęć do podejmowania samodzielnych decyzji, regularnie oprotestowywanych przez jedną lub drugą stronę, bywało, że przez obie. Autorem ok. 3/4 zastrzeżeń i protestów był Senat gdański. Każde z nich, choćby w drobnej części, spadało na barki wysokiego komisarza, który wśród najważniejszych zadań miał mediować i rozwiązywać powstajace problemy w procedurze lokalnej, z branym pod uwagę (założonym?) handicapem słabszego. Każda sprawa wychodząca z Gdańska lub Warszawy jako sporna wymuszała zajmowanie się nią przez Sekretariat LN, bardzo często także przez Radę, nader chętnie salwująca się powołaniem specjalnych komitetów, ekspertów, kierowaniem prośby do Stałego Trybunału o opinię doradczą.

${ }^{19}$ H. Stępniak, Rada portu i dróg wodnych w Wolnym Mieście Gdańsku, Gdańsk 1971, s. 38. Ogromną odwagą wykazał się autor, pisząc o antypolskiej postawie pracowników Sekretariatu LN.

${ }^{20}$ M. Andrzejewski, Najnowsze prace o Lidze Narodów i Wolnym Mieście Gdańsku, „Kwartalnik Historyczny" 1981, nr 3, s. 803.

${ }^{21}$ S. Sierpowski, Między wojnami, t. II, Poznań 1999, s. 272. 
Przeważały spory o charakterze prawniczym, w tym zwłaszcza odmiennie interpretowane zapisy umów i porozumień, wcześniejszych decyzji wysokich komisarzy itp. W wielu wypadkach postępowanie Graviny miało charakter asekuracyjny, gdy kontaktował się z Sekretariatem, zwłaszcza Helmerem Rostingiem, który był - jeśli wolno użyć tego słowa - odpowiedzialny w Sekretariacie Ligi za sprawy gdańskie. W sprawy te niejednokrotnie ingerował osobiście sekretarz generalny, świadom miejsca spraw gdańskich w polityce szerszego wymiaru, w którym trudną - do pominięcia - rolę odgrywały relacje brytyjsko-niemieckie ${ }^{22}$.

Sprawa antypolskiego nastawienia Graviny wymaga pogłębionego spojrzenia. Nie może ono abstrahować od europejskiego kontekstu, jak również formalnych, w części także domniemanych obowiązków wysokiego komisarza, powołanego i zobligowanego do znajdowania rozwiązań umożliwiających pokojowy rozwój stosunków polsko-gdańskich. Można zgodzić się z poglądem, że z punktu widzenia instytucji genewskiej Gravina w pewnych sprawach - np. angażowanie się w reorganizację terytorialną Wolnego Miasta w kierunku utworzenia wolnego państwa - przekroczył zadania, jakie zostały mu powierzone. Nie mniejsze znaczenie miało to, że ten projekt - najbardziej krytykowany i brany za koronny argument niechętnego stosunku Graviny do Polski - był w ogólnych zarysach przedmiotem szczególnego zainteresowania brytyjskiego. Gravina popierając w czasie swojej kadencji projekt zmian, „doskonale zdawał sobie sprawę, że w tym czasie ani Polska ani Gdańsk nie zaakceptuja jego planu. Wierzył jednak, że była to jedyna dostępna opcja i Liga powinna realizację tego projektu wymusić" ${ }^{23}$. Z tym wymuszeniem to gruba przesada.

Tadeusz Piszczkowski, który nazywa Gravinę „komisarzem usposobionym pro-niemiecko, czy też pro-gdańsko", pisze, że był on autorem oryginalnego, „dla Polski bardzo niekorzystnego planu”. Zapoznał z nim Alexandra Cadogana, wówczas kierownika referatu LN Foreign Office. Dokonało się to podczas jego wizyty w Gdańsku w czerwcu 1930 r. Gravina miał za sobą roczne doświadczenia związane $\mathrm{z}$ uczestnictwem $\mathrm{w}$ co rusz wybuchających sporach gdańsko-polsko-niemieckich. Przy końcu 1931 r., dokładnie 15 listopada, całościowy plan „za pośrednictwem Cadogana znalazł się w Foreign Office”24. Poznali go także sekretarz generalny LN Drummond, minister Dino Grandi i lord Robert Cecil, nieco później również Mussolini.

Punktem wyjścia tego projektu było stwierdzenie, że 11 lat istnienia Wolnego Miasta jasno pokazało całkowite niepowodzenie polsko-gdańskiej współpracy gospodarczej. W związku z tym zachodziła konieczność zmiany

${ }^{22}$ Warto poznać inspirujące opracowanie: S. Żerko, Wymarzone przymierze Hitlera. Wielka Brytania w narodowo-socjalistycznych koncepcjach i w polityce III Rzeszy do 1939 r. (Studium niemcoznawcze), Poznań 1995.

${ }^{23}$ E. Tollardo, op. cit., s. 171.

${ }^{24}$ T. Piszczkowski, Anglia a Polska 1914-1939. W świetle dokumentów brytyjskich, Londyn 1975, s. 359; C.J. Burckhard, Moja misja w Gdańsku 1832-1939, Warszawa 1970, s. 13. 
traktatu wersalskiego, art. 100-108, co mogło uchronić od konfliktu zbrojnego, który wydawał się bliski i nieuchronny. Istotę projektu można było sprowadzić do powstania „wolnego państwa Gdańsk”, z własną polityka zagraniczna, ale pod protektoratem LN. W sensie terytorialnym miało być to powiększenie Wolnego Miasta w kierunku zachodnim. Rozszerzenie obejmowałoby północną część polskiego „korytarza”, włączając linie kolejowe łączące Rzeszę z Prusami Wschodnimi, ale z pominięciem enklawy obejmującej Gdynię i otaczające ją tereny nadmorskie. Celem tego rozwiązania miało być ułatwienie komunikacji Niemiec z Prusami Wschodnimi, z pominięciem terytorium Polski. Fizyczny, terytorialny kontakt Rzeszy z Prusami Wschodnimi miał się dokonywać za pośrednictwem „wolnego państwa Gdańsk", mającego równą liczbę polskich i niemieckich mieszkańców i znajdującego się pod protektoratem $\mathrm{LN}^{25}$. Gravina projekt swój przedstawił także Mussoliniemu podczas świątecznego pobytu w Rzymie 31 XII $1931 \mathrm{r}$.

W każdym wypadku najważniejszym elementem propozycji był - zdaniem Graviny - brak alternatywy. Pozostawienie sprawy bez zmian wywoła, wcześniej czy później, ale nieuchronnie, zbrojny konflikt polsko-niemiecki ${ }^{26}$. Znaczy to, że nadrzędnym celem jego projektu była próba rozwiązania pokojowego, do czego jako funkcjonariusz Ligi mógł się czuć upoważniony. Nikt jednak nie oczekiwał od niego wychodzenia z tą inicjatywa, która przekraczała jego kompetencje, aczkolwiek mieściła się w rozszerzającej interpretacji art. 19 paktu Ligi o zmianie traktatów, które mogą zagrażać pokojowi. O wprowadzenie $\mathrm{w}$ życie tego artykułu rozprawiano wielokrotnie $\mathrm{w}$ LN i poza nia. W pewnym sensie trwa nadal w ramach tzw. alternatywnej historii, która dość marnie mieści się $\mathrm{w}$ dyscyplinie naukowej.

We Włoszech żadnych bezpośrednich reakcji na tę inicjatywę nie było. Nie znalazłem informacji, aby podobna propozycja pojawiła się, tym bardziej była rozważana w Genewie. Nie przeniknęła też - nieważne jakimi kanałami - do Polski. Lord Cecil, bardzo oszczędny jeśli chodzi o wspominanie spraw gdańskich, w ogóle ten watek pominął. Jedynie Foreign Office drążyło temat. Powstał tam, z data 9 XII 1931 r., memoriał, który miał posłużyć do rozmów z ministrem Zaleskim. Rozmawiano na temat stosunków polsko-niemieckich, ale sprawy reorganizacji terytorialnej Wolnego Miasta nie podjęto. Zreszta pod wpływem dalszych studiów w Londynie pierwotny projekt Graviny - jeśli przy tym określeniu pozostać - podlegał istotnym modyfikacjom, bo zakładał - w różnych wariantach - przyłączenie Gdańska do Niemiec ${ }^{27}$. Mówimy o pierwszych latach trzydziestych!

Pozostawiam tę sprawę bardziej dociekliwym, dla których teza, że to brytyjski polityk był spiritus movens projektu, który dojrzewał w Gdańsku

\footnotetext{
${ }^{25}$ E. Tollardo, op. cit., s. 171.

${ }^{26}$ E. Deodato, op. cit., s. 129-130; zob. też: ibidem, s. 134, przypis 23.

27 T. Piszczkowski, op. cit., s. 359-360.
} 
dokładnie półtora roku, nie wydaje się absurdalna. Interesujący się tą sprawą Ettore Deodato podaje, że Cadogan przygotowując poufny materiał poświęcony kwestiom gdyńsko-gdańskim 6 VI 1930 r., zawarł opinię dotycząca rozszerzenia terytorium Wolnego Miasta poprzez włączenie północnej części polskiego korytarza i przekształcenia Wolnego Miasta w Free State ${ }^{28}$.

Nie można przy tym porzucić wysoce prawdopodobnych paraleli z narodzinami tzw. paktu czterech. I w jednym, i w drugim wypadku Włochy stałyby się lub miały stać się uczestnikiem generalnego przemeblowania struktury wersalskiej, z której nie były zadowolone. Ważne, że w wielu sprawach solidaryzowały się z państwami pokonanymi, w tym z Berlinem - graczem najważniejszym. Dlatego nitek tego kłębka doszukiwałbym się jednak w Londynie i dominującej tam taktyce nazywanej skrótowo appeasement policy.

Poszukiwania mające na widoku wyjście z gdańskiej matni były powszechne. Wszelkim rozmowom, dywagacjom towarzyszyła dominująca przesłanka, że utrzymanie istniejącego stanu rzeczy nie będzie możliwe. Polityków i opinię publiczną oswajano z przekonaniem, że spór o Gdańsk jest najważniejszym, nierozwiązywalnym konfliktem międzynarodowym, który może doprowadzić do wybuchu wojny o szerszym zasięgu. Dlatego i po prostu różnych propozycji i pomysłów było bardzo dużo. Także absurdalnych, jak np. oddanie Niemcom Gdańska w zamian za Kłajpedę - oczywiście litewską. Czy dla wszystkich absurdalną?

Przedstawianie projektu Graviny jako koronnego argumentu świadczacego o jego antypolskich poglądach nie wydaje się zasadne, aczkolwiek to nie Polska miała być beneficjentem proponowanych przez niego zmian. Z perspektywy wysokiego urzędnika, reprezentującego LN, w jednym z najbardziej zapalnych punktów w Europie, na projekcie Graviny nie tyle miały wygrać Niemcy, ile pokój. W raporcie do Rady z 7 V 1931 r. znajdziemy taką opinię: „Zadanie Ligi Narodów w odniesieniu do Wolnego Miasta jest bardzo jasno określone i staram się, aby zostało ono w pełni wypełnione. Szczególnie mi zależy, aby prestiż Ligi Narodów w Gdańsku był zawsze utrzymywany na poziomie odpowiadającym temu ważnemu zadaniu"29.

Tak też problem ten widzi Elisabetta Tollardo, pisząc, że w gdańskim biurze Graviny nie ograniczano się tylko do obserwacji sytuacji i narzekania na nią w kontaktach z Genewą i stolicami europejskimi. Wychodząc ze swoja inicjatywa, w centralnym miejscu postawił LN, która jednak będzie musiała podjąć dyskusję nad zmianą traktatu wersalskiego ${ }^{30}$.

Mieściło się to w ogólnych planach Włoch, z którymi mógł się solidaryzować jako nacjonalista i miłośnik kultury swojego kraju. Nie korespondowało to jednak z wolą przygniatającej liczby członków LN. W Genewie nadal

\footnotetext{
${ }^{28}$ E. Deodato, op. cit., s. 137, przypis 31. Należy zauważyć, że Cadogan materiał ten opracował po powrocie z Gdańska. Zob. E. Tollardo, op. cit., s. 204, przypis 85.

${ }^{29}$ „Journal Officiel de la Société des Nations” 1931, s. 1478.

${ }^{30}$ E. Tollardo, op. cit., s. 371.
} 
dominowało przekonanie, że naruszenie jednej cegiełki gmachu wersalskiego może być zaczynem jego destrukcji.

Uzasadnione wydaje się też rozważniejsze ferowanie opinii o realizacji przez Gravinę na terenie Gdańska polityki włoskiej. Italia w tym rejonie nie uprawiała aktywnej polityki, chyba że na złość Francji. Sprawy związane ze wschodnią częścią Europy - na zasadzie podziału ról - były w Rzymie na dalszym planie. Dominowały problemy śródziemnomorskie i kolonialne. Gravina utrzymywał sporadyczne kontakty z przedstawicielami rządu, ministrem spraw zagranicznych, włoskimi urzędnikami w Sekretariacie LN, spotkał się nawet z Mussolinim. Za trafną uznaję jednak opinię Deodaty, że nie spowodowało to „powstania zależności Wysokiego Komisarza od wytycznych rządu faszystowskiego. Tylko jeden raz Rafael Guerilla na polecenie ministra Grandiego, wskazywał otwarcie w jaki sposób ma się zachować Gravina. Stało się to dopiero w lipcu 1932 roku". Autor ten uznając powołanie na stanowisko wysokiego komisarza za „niezaprzeczalne osiagnięcie dyplomacji włoskiej”, przyznaje zarazem, że nadzieje Palazzo Chigi na wykorzystanie Graviny do własnych celów nie były satysfakcjonujace ${ }^{31}$.

Znacznym zawirowaniem w funkcjonowania urzędu Wysokiego Komisarza w Gdańsku była niespodziewana śmierć Graviny 19 IX 1932 r., po krótkiej chorobie. Miał 49 lat. Bardziej zrozumiałe jest w związku z tym jego zastrzeżenie, gdy wyrażając zgodę na drugą kadencję w Gdańsku, wspomniał o możliwości ustapienia ze względów „zdrowotnych lub rodzinnych”. Po kilku miesiącach jego następca informował Radę, że ta niespodziewana śmierć była głęboko przeżywana przez całą ludność Wolnego Miasta, która bez wyjątku w sensie społecznym i politycznym „chciała złożyć przedstawicielowi Ligi Narodów poruszające świadectwo jego uznania i przywiązania. Pogrzeb był bardzo uroczysty, co podkreślał udział przedstawicieli Senatu, rządu polskiego, konsulów rezydujących w Gdańsku, Rady Portu oraz licznych urzędników Wolnego Miasta” oraz kilku tysięcy mieszkańców Gdańska ${ }^{32}$.

Zgodnie z na ogół przestrzeganą tradycją Sekretariat zadbał o specjalne upamiętnienie przedstawiciela LN w Gdańsku, zmarłego w czasie pełnienia służby. Pod przewodnictwem Eamona de Valery 23 IX 1932 r. Rada oddała hołd pamięci Manfrediego Graviny. W imieniu Wolnego Miasta przemawiał Johann Ferber, który podkreślił, że Gravina do realizowanego z woli LN zadania wniósł cechy byłego żołnierza i dyplomaty - odwagę i takt. W wykonywaniu swoich obowiązków korzystał ze związanych z nimi cech zawodowych, połączonych z życzliwa inteligencja; był przenikliwy, a w swoich wystapieniach wyrazisty. Pozostawił wielu oddanych przyjaciół, a LN utraciła jednego z jej najbardziej oddanych sług.

${ }^{31}$ E. Deodato, op. cit., s. 134.

32 „Journal Officiel de la Société des Nations” 1934, s. 988-989, Raport z 1.06.1933 r. Ekshumacji dokonano 15 października i specjalnym wagonem trumna została przewieziona do Włoch. Płyta kamienna upamiętniająca Gravinę pozostała na cmentarzu w Gdańsku. 
Równoważnego głosu polskiego nie było. Przemawiał natomiast dobrze znany w środowisku genewskim Pompeo Aloisi, kompan zmarłego z czasów służby na morzu. To właśnie w tych warunkach, bardziej niż w innych, można poznać cechy i wartość człowieka, którego dziś zgodnie żałujemy. Nawiązał też do rozpoczętej drugiej kadencji na stanowisku wysokiego komisarza w Gdańsku. Była dowodem wielkiego zaufania ze strony LN i świadczyła o uznaniu dla wybitnego dyplomaty, który doskonale rozumiał sytuację polityczną miejsca swego działania. Odszedł żołnierz, pisarz, dyplomata, człowiek szlachetny i taki pozostanie jako reprezentant Włoch, działajacy w służbie dobrej sprawy ${ }^{33}$.

Niespodziewana śmierć Graviny przyczyniła się nie tylko do popularyzacji jego osoby, ale także spraw gdańskich. Pewien udział w tym miała trzykrotnie wznawiana broszura pokazujacca sytuację w Gdańsku, wydana w 1933 r. w Rzymie. Jej autorem był Raffaele Guariglia, szef Biura ds. Europy Wschodniej w Palazzo Chigi ${ }^{34}$.

Nie wpłynęło to jednak na zagwarantowanie dla Graviny miejsca w historiografii włoskiej. W stosunkowo świeżej monografii, której autorka jest Enrica Costa Bona, noszącej tytuł L'Italia e la Società delle Nazioni, Gravina figuruje dwa razy - raz w kontekście sporu między Gdańskiem i Gdynią i drugi raz, że w ogóle na stanowisko w Gdańsku został powołany; w sumie kilka wierszy. Kilkakrotnie cytowani w tym tekście tacy autorzy, jak Deodato czy Tollardo wskazuja, że materiał wyjściowy jest bogaty i dostępny. Niezły stosik dokumentów można znaleźć w Archiwum Ligi Narodów, o polskich i niemieckich nie mówiąc. Zapewne uznano, że zasługi Graviny jako przedstawiciela LN w Gdańsku są z punktu widzenia polityki włoskiej znikome i mało ważne. W kilku znanych mi syntezach dotyczacych polityki zagranicznej Włoch Gravina nie występuje. Oznacza to, że jego nazwisko najczęściej figuruje w dorobku polskiej historiografii, do czego także przysłuży się być może ten artykuł.

\section{Streszczenie}

Powstanie Wolnego Miasta Gdańska było próbą realizacji zapowiedzi dobitnie zawartej w programie pokojowym Woodrow Wilsona o powstaniu Polski z wolnym dostępem do morza. Traktat wersalski opiekę nad tą terytorialną enklawą powierzył Radzie Ligi Narodów, która wykonywała swą powinność za pośrednictwem wysokich komisarzy rezydujaccych w Gdańsku. Ich wybór był źródłem kontrowersji i sporów. Ujawniły się one dość silnie po wejściu Niemiec do LN w 1926 r. i uczestniczeniu w posiedzeniach Rady LN ze stałym mandatem. Desygnowanie wysokich komisarzy wymagało jednomyślnej akceptacji członków Rady, jak również zgody Senatu Wolnego Miasta i rządu polskiego. Manfredi Gravina, polityk i oficer z Włoch, został wybrany na trzyletnią kadencję, obejmująca lata 1929-1932, bez perturbacji. Popierał go rząd niemiecki (a więc i Senat Wolnego Miasta); sprzeciwów nie zgłaszała

33 „Journal Officiel de la Société des Nations” 1933, s. 1720, aneks 3114.

${ }^{34}$ R. Guariglia, La question de Danzig, Rome 1933. 
Polska. Gravina był od 1923 r. członkiem partii faszystowskiej we Włoszech; prognozował sukces hitleryzmu w Niemczech. Między innymi z tych powodów został uznany w polskiej historiografii za urzędnika Ligi, który realizował w Gdańsku politykę proniemiecką lub progdańska, więc eo ipso antypolska. Koronnym argumentem świadczącym o tej podstawie była propozycja z końca 1931 r., sformułowana po półtorarocznych doświadczeniach w Gdańsku, zakładająca pewne korekty terytorialne, które miały umożliwić Niemcom omijanie terytorium Polski w ich kontaktach z Prusami Wschodnimi. Ten kontakt miał się dokonywać przez terytorium „wolnego państwa Gdańsk”, prowadzącego własną politykę zagraniczna, aczkolwiek nadal znajdującego się pod protektoratem LN. Projekt ten, znany kilku osobom, w tym sekretarzowi generalnemu LN Ericowi Drummondowi, powstawał w swoistej kooperacji z Alexandrem Cadoganem, szefem biura LN Foreign Office. Tam też był nadal rozwijany. Brak jakichkolwiek śladów, aby projekt ten znał rząd polski; nie stanowił też obiektu zainteresowania LN ani rządu włoskiego. Niewątpliwie budowany z założeniem strat terytorialnych przez Polskę wypływał z konstatacji, że pozostawianie Gdańska w istniejącym stanie rzeczy grozi - wcześniej czy później, ale niewątpliwie - wybuchem wojny. Znaczy to, że nadrzędny cel projektu Graviny stanowiło podjęcie próby rozwiąania pokojowego, do czego jako funkcjonariusz Ligi był predestynowany. Nikt jednak nie oczekiwał od niego wychodzenia z inicjatywa, która przekraczała jego kompetencje, aczkolwiek mieściła się w rozszerzajacej interpretacji art. 19 paktu Ligi o zmianie traktatów, które moga zagrażać pokojowi. Ważnym argumentem torpedujacym twierdzenie o antypolskim nastawieniu Graviny była akceptacja przez rząd polski jego wyboru na drugą kadencję w $1931 \mathrm{r}$. To ewenement świadczący o pozytywnej ocenie jego działalności w Gdańsku nie tylko przez członków Rady, ale także Senat Wolnego Miasta Gdańska i Polskę. Opinii tej Gravina nie miał jak zmienić, bo kwartał po rozpoczęciu drugiej kadencji zmarł.

\section{Judgement upon Manfredi Gravina, High Commissioner of the League of Nations in the Free City of Danzig from 1929 to 1932}

The Free City of Danzig (Gdansk) (FCD) establishment attempted to fulfil the promise made in Woodrow Wilson's peace programme about creating Poland with free access to the sea. The Treaty of Versailles entrusted the care of this territorial enclave to the Council of the League of Nations, which performed its duty through High Commissioners residing in Danzig. Their choice was a source of controversy and disputes. These became quite apparent after Germany joined the League of Nations in 1926 and participated in the Council of the LN sessions with a permanent mandate. The appointment of High Commissioners required the unanimous approval of the Council members and the consent of the FCD Senate and the Polish Government. The election of Manfredi Gravina, an Italian politician and officer, for a three-year term covering the years 1929-1932, took place without perturbations. He was supported by the German Government (and thus by the FCD Senate) and had no objections from Polish Minister August Zaleski. Gravina had been a member of the Fascist Party in Italy since 1923; he predicted the success of Hitlerism in Germany. For these reasons, among others, he was recognised by Polish historiography as a League official who pursued a pro-German or pro-Danzig policy in the FCD, thus eo ipso anti-Polish. The crowning argument testifying his attitude was a proposal formulated in late 1931, after eighteen months of experience in Danzig, assuming certain territorial adjustments to enable the Germans to bypass Polish territory in their contacts with East Prussia. These contacts were to take place through the Free City of Danzig territory, which pursued its own foreign policy, albeit still under the protectorate of the League of Nations. This project, known to several people, including LN Secretary-General Eric Drummond, was developed in peculiar cooperation with 
Alexander Cadogan, head of the League of Nations Section of the Foreign Office. And it was there that the project continued to be developed. There is no evidence that it was known to the Polish Government, nor was it of any interest to the League of Nations or the Italian Government. Although the plan assumed some territorial losses on the part of Poland, it resulted from the conclusion that leaving Danzig in its existing state of affairs would - sooner or later, but undoubtedly - lead to the outbreak of war. It meant that the ultimate aim of Gravina's project was an attempt at a peaceful solution, for which, as a League officer, he was perfectly predestined. No one, however, expected him to come up with this initiative, which was beyond his competence, although it fell within the broader interpretation of Article 19 of the League's Covenant on amending treaties that might endanger peace. An important argument that torpedoed the claim that Manfredi Gravina was anti-Polish was the Polish Government's acceptance of his election for a second term in 1932. It testified to a positive assessment of Gravina's activities in Danzig not only by the members of the LN Council but also by the FCD Senate and Poland. This opinion could not be spoiled by Gravina, as he died three months after the beginning of his second term. He was 49 years old.

\section{Bibliografia}

Andrzejewski M., Najnowsze prace o Lidze Narodów i Wolnym Mieście Gdańsku, „Kwartalnik Historyczny" 1981, nr 3.

Deodato E., Manfredi Gravina - Wysoki Komisarz Ligi Narodów w Gdańsku, (czerwiec 1929 - wrzesień 1932), „Studia Historica Slavo-Germanica” 1989, t. XV.

Ginneken A.H.M. van, Historical Dictionary of the League of Nations, Oxford 2006.

Kimmich Ch.M., The Free City Danzig and German Foreign Policy 1919-1934, New HavenLondon 1968.

Mikos S., Wolne Miasto Gdańsk a Liga Narodów 1920-1939, Gdańsk 1979.

Piszczkowski T., Anglia a Polska 1914-1939. W świetle dokumentów brytyjskich, Londyn 1975. Ramonat W., Der Völkerbund und die Freie Stadt Danzig 1920-1934, Osnabrück 1979.

Sierpowski S., Liga Narodów w najlepszym czasie 1926-1929, Poznań 2018.

Sierpowski S., Między wojnami, t. II, Poznań 1999.

Stępniak H., Rada portu i dróg wodnych w Wolnym Mieście Gdańsku, Gdańsk 1971.

Tollardo E., Fascist Italy and the League of Nations, 1922-1935, London 2016.

Walters F.P., History of the League of Nations, Oxford 1952.

Żerko S., Wymarzone przymierze Hitlera. Wielka Brytania $w$ narodowo-socjalistycznych koncepcjach i w polityce III Rzeszy do 1939 r. (Studium niemcoznawcze), Poznań 1995.

Stanisław Sierpowski - prof. zwyczajny, od 2012 r. prof. senior Uniwersytetu im. Adama Mickiewicza; historyk dyplomacji, stosunków międzynarodowych XX w. Od lat osiemdziesiątych zajmuje się historią Ligi Narodów i regionalistyką. E-mail: stansierp@op.pl.

Stanisław Sierpowski - full Prof., since 2012 Senior Professor of the University of Adam Mickiewicz; historian of diplomacy and international relations of the 20th century. Since the 1980s, he has been interested in the history of the League of Nations and regional studies. E-mail: stansierp@op.pl. 